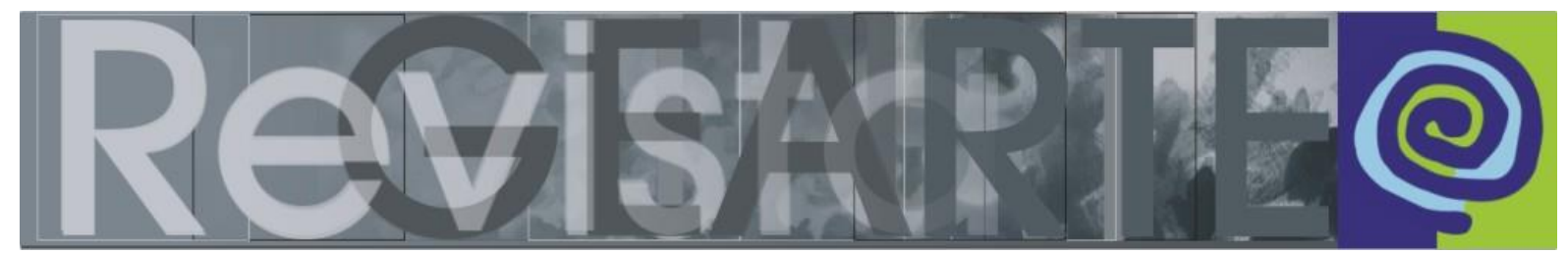

ISSN 2357-9854 | e-ISSN 2596-3198 (online)

\title{
Ser e Estar professor em modos de fabular
}

\author{
Carolina Ramos Nunes \\ (Universidade do Estado de Santa Catariana UDESC, Florianópolis/SC, Brasil) \\ Elaine Schmidlin \\ (Universidade do Estado de Santa Catariana UDESC, Florianópolis/SC, Brasil)
}

\begin{abstract}
RESUMO - Ser e Estar professor em modos de fabular - Este texto problematiza a relação entre ser e estar professor em uma escrita, pautada na fabulação, que pode vir a contribuir com a formação docente em Artes Visuais, compreendida não como a representação de um ideal, mas como uma diferença. Como referência teórica, o trabalho pauta-se na faculdade fabuladora, retomada de Henri Bergson por Gilles Deleuze, de modo a potencializar a criação entre arte e vida, uma vez que abre no real a possibilidade do acontecimento - que se apresenta não como profundidade a ser alcançada, mas como superfície - em que pode vir a emergir variáveis intensivas de um pensamento sem imagens naquela formação.
\end{abstract}

PALAVRAS-CHAVE

Formação docente. Artes Visuais. Fabulação. Diferença. Acontecimento.

\begin{abstract}
The act and state of being a teacher in ways of fabulating - This text problematizes the relationship between the act and state of being a teacher in a writing, guided by the fable, which may contribute to the teaching formation in Visual Arts, understood not as the representation of an ideal, but as a difference. As a theoretical reference, this work is guided by the fabulizing faculty, taken up by Henri Bergson by Gilles Deleuze, in order to enhance the creation between art and life, since it opens up in the real the possibility of the event - which presents itself not as a depth to be achieved but as a surface - in which intensive variables of a thought without images may emerge in that formation.
\end{abstract}

KEYWORDS

Teacher training. Visual Arts. Fabulation. Difference. Event.

RESUMEN - Ser y Estar docente en formas de fábula - Este texto problematiza la relación entre ser y estar docente en un escrito, guiado por la fabulación, que puede llegar a contribuir a la formación docente en Artes Visuales, entendida no como la representación de un ideal, sino como una diferencia. Como referencia teórica, la escritura se guía por la facultad fabuladora, retomada de Henri Bergson por Gilles Deleuze, para potenciar la creación entre el arte y la vida, ya que abre en lo real la posibilidad del acontecimiento - que se presenta no como profundidad a alcanzar, sino como superficie - en que en esa formación pueden surgir variables intensivas de pensamiento sin imágenes.

PALABRAS CLAVE

Formación de profesores. Artes visuales. Fabulación. Diferencia. Acontecimiento. 


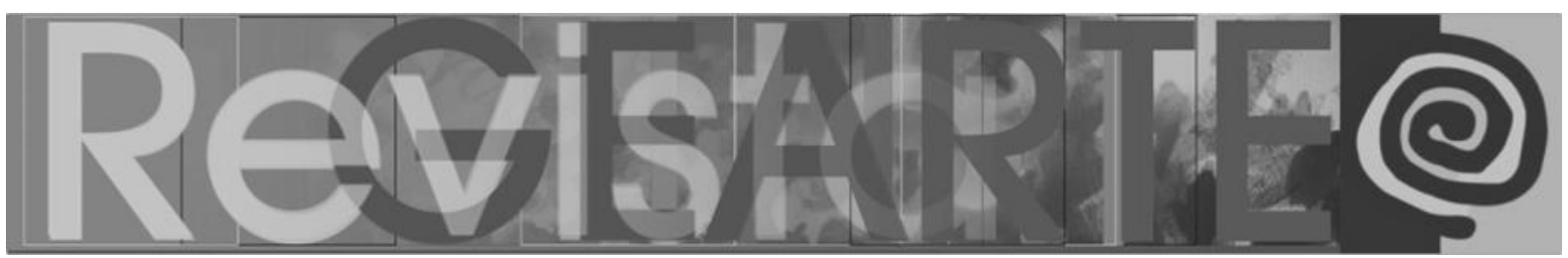

Estávamos escrutando aquela escuridão atravessada de vozes, quando ocorreu a mudança: a única verdadeiramente grande mudança que me foi dado presenciar, diante da qual o resto nada significa. Em suma: aquela coisa que começou no horizonte, aquela vibração que não se assemelhava ao que agora chamávamos de som, nem nada do gênero "algo está nos tocando!", ou outros mais; uma espécie de ebulição certamente distante e que ao mesmo tempo nos parecia próxima; enfim, de repente a escuridão se fez escura em contraste com algo que não era escuro, ou seja, a luz. Ítalo Calvino, em Ao nascer do dia (de Todas as cosmicômicas).

Nesta escrita em fabulação ${ }^{1}$, tal como descreve o personagem Qfwfq na trajetória de alguns contos no livro Todas as cosmicômicas (CALVINO, 2007), as vizinhanças não são territórios, mas tempos que não são cronológicos, e sim de outra ordem, afunilados e condensados, em pontos cujas narrativas acontecem. Embora os territórios estejam presentes, é na relação com a terra e com o universo/caos que se desenrolam as criações do velho contador de histórias, em Ítalo Calvino.

Permito-me, assim, transitar entre vizinhanças, não aportando nem na arte nem na filosofia. Prefiro conversar em um plano pré-filosófico, em que a arte e a filosofia transitam com suas figuras e conceitos, para que eu possa deles pinçar linhas de força para uma pesquisa sobre a formação inicial do professor de Artes Visuais.

Tomo por liberdade aproximar algumas potências nesta escrita ficcional, que julgo importante citar logo de início: a arte, a filosofia, o ser professor e o estar professor em formação, além da fabulação, como força que arrasta intensivamente as identidades representacionais presentes naquela formação.

Deleuze, como filósofo do pensamento sem imagens, diz que "o primado da identidade, seja qual for a maneira pela qual esta é concebida, define o mundo da representação" (DELEUZE, 2006, p. 15). Em contrapartida, "o pensamento moderno nasce da falência da representação, assim como da perda das identidades e da descoberta de todas as forças que agem sob o idêntico. O mundo moderno é o dos simulacros" (DELEUZE, 2006, p. 15). 


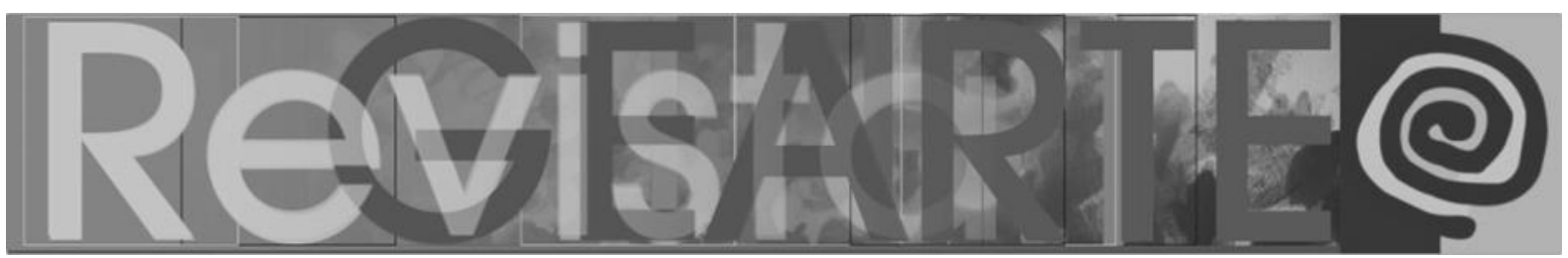

$\mathrm{Na}$ verdade, a liberdade aqui se torna libertinagem de simulacros, ou até mesmo imprudência ousada, por colocar tantos atravessamentos que podem criar um caos em poucas páginas digitadas.

\section{Uma escola na esquina do universo}

Era uma vez...

Assim começa a escrita sem impor uma forma de expressão a uma matéria vivida, pois escrever está ao lado do informe, sendo apenas um processo que atravessa o vivível e o vivido, instaurando na escrita uma zona de vizinhança, indiscernível, tal que não seja possível distinguir-se em uma única forma (DELEUZE, 2011, p. 11).

Era uma vez uma escola como todas as outras. Percebo que as salas e as paredes eram as mesmas. Concordo que a escolha das cores das paredes poderia ser de cores mais claras. Anoto este detalhe para falar com a diretora na próxima oportunidade, pois aquele verde-escuro em nada colabora no aprendizado (que não me ouçam os outros - sim, vocês sabem quem são os outros).

No pátio, barulhos e andanças, como todo intervalo. Grupos aqui, grupos por lá. Espalhados, mas uníssonos. Recebemos uma notificação de que não seriam mais permitidos brinquedos que pudessem causar acidentes; entre eles estava o pião, sendo que as bolinhas de gude entraram na lista por uma iniciativa que tomava em consideração os alunos menores (pois os estudantes andam entrando cada vez mais cedo no ambiente escolar) ${ }^{2}$. Hoje, no pátio, fingi que não vi nada e entrei em uma sala onde se encontravam outros professores.

Neste lugar, "estamos diante de uma complexidade de tal magnitude que, acredito, teria de tomar algumas decisões a respeito da 'figura do professor': seria o desejo de ensinar, de empreender uma travessia junto a outras idades? Uma figura ética e/ou jurídica? [...] Acatamento, adaptação, indiferença ou rebelião?" (SKLIAR, 2019, p. 34). 


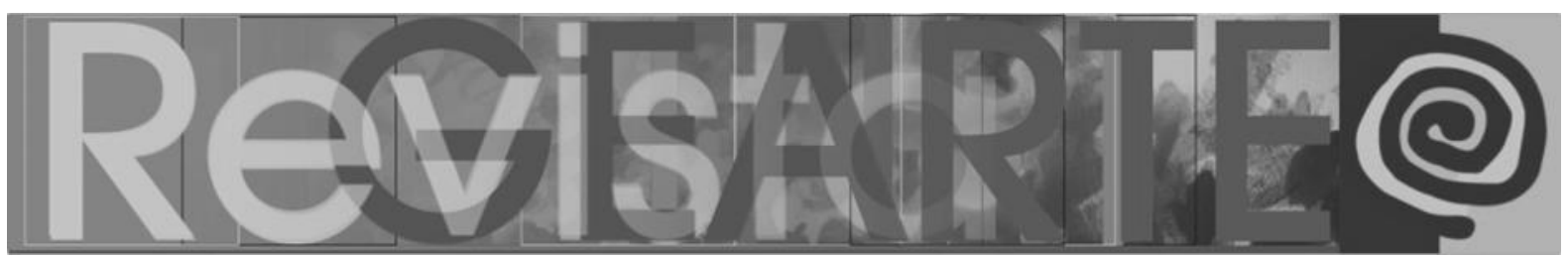

Enquanto isso, dois professores entravam na sala com os bolsos cheios de bolinhas de gude. Um deles as jogou sobre a mesa, em meio aos objetos do café, feliz com o fato de que aquele seria o último dia daqueles profanos objetos na escola. Inflamado, ele ainda reiterava a necessidade urgente de reconsiderarmos o modo como os intervalos estavam sendo conduzidos, já que os estudantes estavam demorando muito para retomar a concentração nos conteúdos depois do retorno às salas de aula. $\mathrm{O}$ outro professor permanecia quieto, desviando o olhar e tomando breves goles de uma xícara de café, sentado no sofá, longe do burburinho.

Não resisti. Sorrateiramente sentei-me ao lado dele e aguardei os demais saírem daquele lugar. Por curiosidade, questionei-o sobre o porquê de seus bolsos estarem com algumas bolinhas de gude e, também, pelo fato de ele não as ter deixado na "caixa da censura" (como eu a chamava). Ainda que risonho, mas contido, ele me contou que aquela pequena quantidade era o resto de uma pequena coleção. As demais ele havia perdido, em um acalorado jogo com os estudantes das séries mais avançadas. Confessou-me também a tristeza de que a memória de infância que ele partilhava com os alunos, até então, não seria mais possível com as novas regras. Concordei com a cabeça baixa, tentando pensar sobre o quanto a infância poderia ensinar à figura do professor.

\begin{abstract}
A infância poderia ser esse instante da parada, da invenção, da atenção desatenta e da percepção extrema. [...] Infância com esse significado é a inutilidade mais importante da vida e da história: o nascimento com suas reticências, o porvir, o que se abre ao tempo e o perfura com sons impensados, a fantasia no coração e nas primeiras palavras, a atenção que se perde na trilha de formigas ou diante de nuvens... (SKLIAR, 2019, p. 125).
\end{abstract}

Então, no retorno dos outros professores à sala, eu e meu cúmplice nos afastamos rapidamente como se nada tivesse acontecido. No pátio, o último encontro das duas últimas bolinhas de gude coincidiu com o toque da ponta de ferro do pião de madeira no cimento, e, ao mesmo tempo, o sinal soou. E, nesse instante infinitesimal, as ordens se desfizeram, os horizontes se romperam, e estava eu a vislumbrar uma esquina, como se a infância tivesse me tomado por 


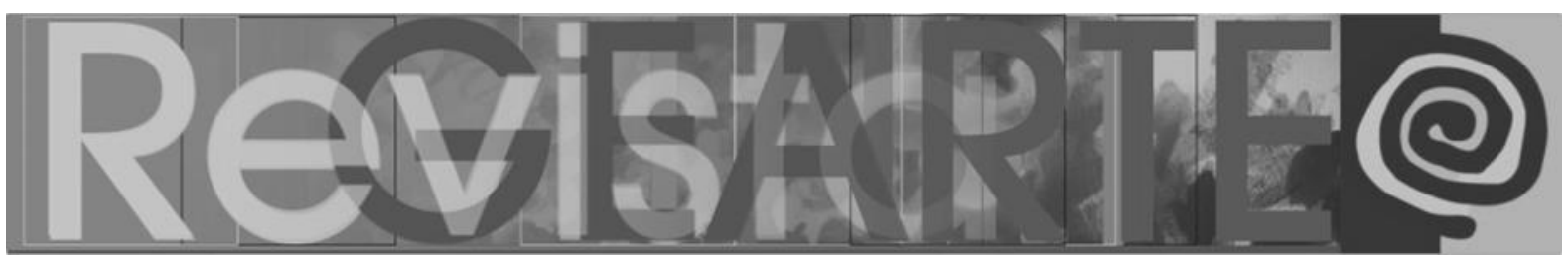

completo ao abrir o tempo e o perfurar, naquele exato momento. Não era qualquer esquina. Essa esquina era o endereço de outra escola; reconheci logo de imediato pelo muro, pelas cores e pelo nome imponente na fachada. Mas não era qualquer escola. Eu estava vendo a escola localizada na esquina do universo.

Imaginava-se que o universo não teria esquinas. Ora, por que uma esquina numa imensidão? Ora, por que não? Nessa esquina específica (seja ela única ou não), próximo de uma estrela e distante de outra, na constelação que lhe pertence, estava uma escola. Não cabe aqui citar seu endereço postal, pois as correspondências não seriam recebidas de todo modo. A escola ainda está aprimorando seu serviço de mensagens em busca de melhores contatos, mas ouso esperar que esta escrita nos aproxime.

Antes de mergulhar nesse lugar diante dos meus olhos, uso a pausa temporal causada pelo relógio, que ouso dizer durou uns bons minutos, para exercer o pensar enquanto conceito filosófico, a fim de preparar-me para o que estava por vir. Diante dessa perspectiva, tomo o cuidado para não cair na velha falácia de que a grama do vizinho é sempre mais verde, ou o que isso possa significar para a educação: os projetos alheios são tentadores e funcionam de forma tão orquestrada que não se percebe qualquer nota desafinada ou ruptura rítmica. Mas, como foi enfatizado, ao olhar para essa fenda no universo, não me compete desejar ambiciosamente o que é distante, mas sim o que está perto em razão desse fortuito evento cósmico ocasionado pela colisão temporal entre o pião, as bolinhas de gude e o soar do sinal.

Em continuidade, tomo o cuidado de manter, desde já, durante o próprio exercício do pensar, um registro atento e disciplinado do que pode vir a acontecer. Atento por reconhecer que os detalhes são de extrema importância em um todo. Disciplinado por considerar que a atenção é um exercício, que demanda organização, contiguidade e vivacidade nos registros. 


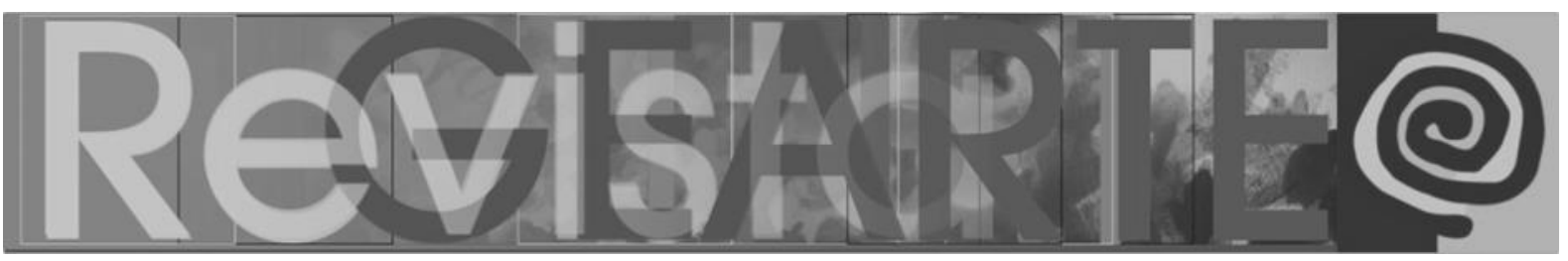

Ainda, em uma última ponderação, permitir-me-ei viver, seguindo o que Bergson (1978, p, 173) escreveu: "Antes de filosofar, é preciso viver". Para que os registros neste mundo sejam, além de relevantes para a educação em arte, vivenciados, para que se possa, então, ter material para filosofar.

Sem mais demora, entro na fenda sem me preocupar em como voltar, sabendo que, de algum modo, retornaria.

\section{Prelúdio}

Aqui, nesta esquina, onde se situa esta outra escola, tem-se a noção diferenciada de um ser professor de um estar professor. Pouso ao lado da janela da sala dos professores. Ouço com atenção o debate acalorado entre dois professores que parecem filosofar sobre a profissão. Depois de incontáveis minutos, o sinal soa ao fundo, eles se despedem e retornam, cada um, para sua sala de aula. Ao ouvir essa conversa neste outro lado do universo, vejo que eles têm uma noção diferenciada entre ser professor e estar professor. Embora em outras línguas o verbo seja o mesmo, ou ainda, seja expresso de formas diferentes, em português temos a possibilidade de ousar com eles.

$\mathrm{Na}$ ferramenta Google, usada de forma difundida em recursos virtuais em substituição aos antigos e maciços dicionários de papel, temos as seguintes definições etimológicas:

'ser' - etim. lat. sedĕo, es, sēdi, sessum, sedēre - 'estar sentado, assentarse, ficar sentado'; fundido com formas do v. lat. esse, 'ser'.

'estar' - etim. sto, as, stēti, stātum, āre - 'estar de pé, em posição vertical, firme'.

Não contente com minha busca etimológica, recorri a outro dicionário virtual, Michaelis, cuja impressão ainda existe:

'ser' - etim. sedēre - traduzido do latim: 'assento'. 


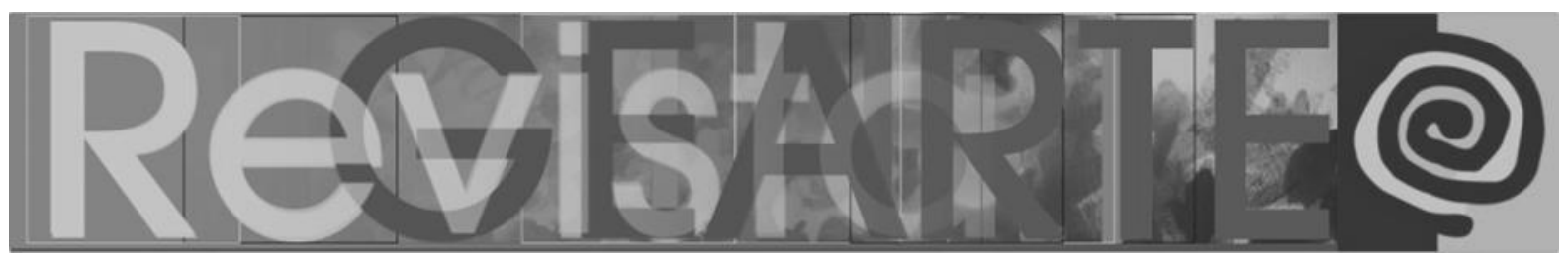

'estar' - etim. stāre - traduzido do latim: 'ficar de pé'.

Sintetizo, para fins de continuidade, ser como uma postura passiva e estar como uma postura ativa.

Quando nomeio as palavras ser professor e estar professor, faço uso dessa breve noção linguística para marcar um ponto: ser professor, para esta pesquisa, dentro deste contexto, condiz com uma postura de passividade em relação a prática docente, enquanto que estar professor pode ser uma posição que ativa a prática docente para pensá-la como uma diferença a ser produzida pelo acontecimento ${ }^{3}$. Nesse caso, a diferença é uma produção em si mesma, "em uma relação do diferente com o diferente, independentemente das formas de representação que as conduzem ao mesmo e as fazem passar pelo negativo" (DELEUZE, 2006, p. 16).

Mas, para que haja acontecimento, é preciso entender que passividade ou impulso ativo não é algo inato ao docente, influenciado que é por carga horária, instituição em que leciona ou por turmas e turnos em que este trabalha. A noção de ser e estar professor, buscada com esta pesquisa, envolve a noção de que o professor é afetado por todas aquelas condições que the são exteriores ao exercício da docência e que, de algum modo, pode introduzir outras e novas formas docentes.

Para isso, vou adiantar a que postura filosófica estou convidando você e meus colegas professores para tomar um café. Como visto, Deleuze será o maior intercessor ${ }^{4}$ que utilizarei para criar conversas com a arte e a filosofia. Junto dele ainda há outros tantos que se aproximarão de forma tão abrupta tal como se afastarão, mas que, por hora, deixarei a surpresa do acaso nos acometer.

Nessas conversas, partilharemos a noção de filosofia enquanto criação de conceitos, mais especificamente do pensar como criação filosófica. Para criar, tanto em filosofia quanto na arte ou na ciência, pensar envolve um abalo não sendo, portanto, algo inato ao sujeito que pensa. E é sobre esse pensar que o ser 


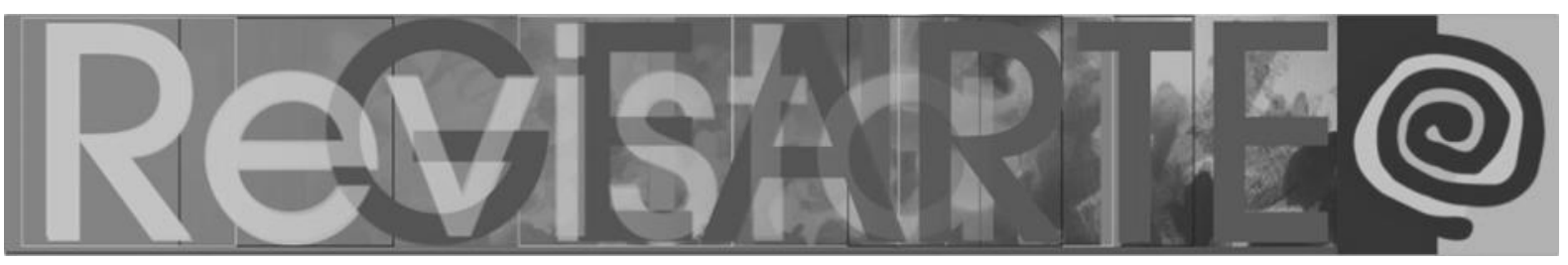

e estar professor, neste texto, estão relacionados. A postura de um pensamento como uma noção ativa, não reflexiva (aqui a reflexão está relacionada com o espelho - um reflexo seria a reprodução de uma ideia apresentada).

Talvez esta proposta esteja mais próxima de um convite criado pelo Chapeleiro Louco e eu, mais próxima da Lagarta do que qualquer outro personagem, pois isto é uma fabulação! Esse é um convite para tomar a ficção em sua força política como movimento que possa agir no mundo em um fabular que se difere da aposta de entender o mundo como lugar natural da verdade, mas como lugar da pluralidade, tanto da mentira quanto da verdade, pois são também efeitos de escritas e imagens que povoam o mundo na possibilidade de outro real (ANDRADE; SCARELI, 2016, p. 82).

Desse modo, ser e estar professor poderiam ser tomados pela potência de criação para (re)inventar-se como docente. Tomo um breve gole de café para deixar claro que não está se negando a noção histórica, cultural e social do professor, muito menos as referências ou a importância do conhecimento na área educacional até hoje fornecido dentro e fora das universidades; pelo contrário, suscito a possibilidade de usar estes e outros materiais de forma contextualizada e sob a influência da criação como força motriz para pensar outros modos de ser e estar docente.

Mas ora, diria o agitado e impaciente coelho de Lewis Carroll, como fazer disso tudo um texto? Ou, ainda mais, como possibilitar o espaço do pensar sem que seja você o vilão que cria e cuida do espelho que está logo ali assombrando os leitores? Acredito ser este o mais trabalhoso, difícil e talvez (digo talvez) inatingível processo nesta proposta: como mensurar o ser ou o estar professor? Há platôs estáveis? Para esta conversa trago para mais perto as noções de acontecimento e fabulação já enunciadas acima. 


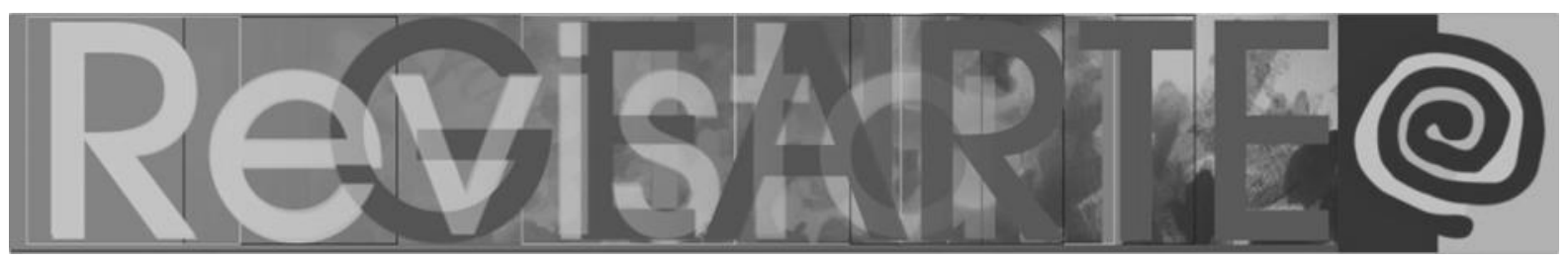

\section{Um passeio na vizinhança}

A filosofia é o território que uso como partida para esta jornada, uma terra longínqua rodeada por desertos sem rotas preestabelecidas, apenas com algumas coordenadas demarcadas por outros que por ali transitaram. Nesse sentido, a terra "não é um elemento entre os outros, ela reúne todos os elementos num mesmo abraço, mas serve de um ou de outra para desterritorializar o território" (DELEUZE, 1997, p. 103).

Já a polarização entre ser e estar professor apresenta a superfície cuja escrita pretendo explorar. Bairros vizinhos cujas semelhanças podem ser próximas, mas as posturas de seus moradores compelem a práticas bem distintas. O ser professor indica um estado permanente, posição pétrea que se adquire com alguns anos passados na academia. Já o estar professor pode ser o desencadeamento de inimagináveis formas que desmontam convicções, potencializadas pelas forças no exercício da fabulação.

Assim, a fabulação será a narrativa que atravessa a realidade e a ficção, criando (ou desejando criar) uma ruptura em quem, corajosamente, percorrer essas linhas, provocando um pensar que "não é nem um fio estendido entre um sujeito e um objeto, nem uma revolução de um em torno do outro. Pensar se faz na relação entre o território e a terra" (DELEUZE, 1997, p. 103).

Sou do outro lado do universo, uma vizinha: não sou professora quando mediadora, não sou mediadora quando professora, não sou acadêmica quando professora e mediadora. Sou vizinha de mim mesma enquanto estou. O paradoxo ser-estar pode parecer cacofônico e até catatônico, mas será explícito para marcar com as costas da unha a escrita a seguir.

O ser professor fecha percursos, define uma formação em uma forma. Não é uma força, ou forças, mas um horizonte-limite, que argamassa um muro feito de tijolos de memórias cristalizadas sobre professores que tivemos, e um cimento de teorias que, de maleáveis, passam a rígidas e impermeáveis estruturas. Enquanto 


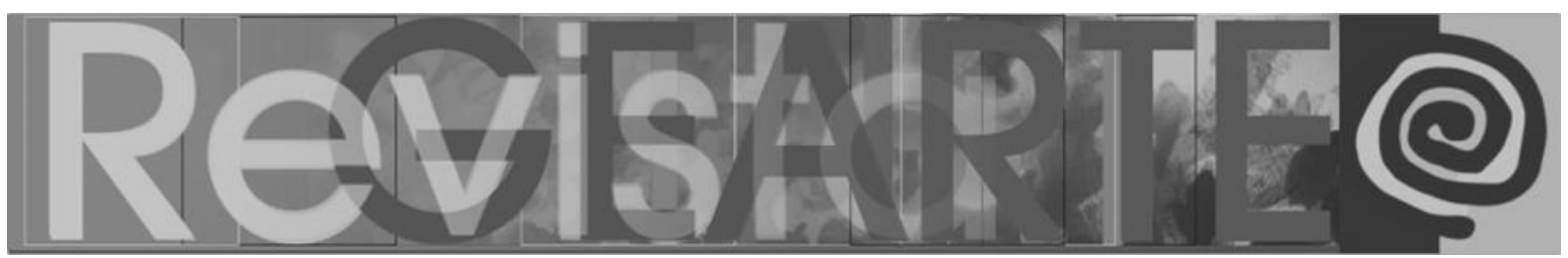

estar professor abre-se ao acontecimento, em uma constante instável, a devires infinitos, configurando-se como moradores inquietos de um bairro pequeno e não muito sofisticado. Algumas ruas demarcam o começo e o fim da vizinhança com outros estados de espírito. O contorno delas é irregular e, algumas vezes, inexistente: algumas encruzilhadas atravessam esses loteamentos. Para Deleuze (2011, p. 11),

\begin{abstract}
Devir não é atingir uma forma (identificação, imitação, Mimese), mas encontrar a zona de vizinhança, de indiscernibilidade ou de indiferenciação tal que não seja possível distinguir-se de uma mulher, de um animal ou de uma molécula: não imprecisos nem gerais, mas imprevistos, não-preexistentes, tanto menos determinados numa forma quanto se singularizam numa população.
\end{abstract}

Ainda em estado de devir, imaginei como seria se eu escapasse pelo portão dessa escola localizada na esquina do universo, para explorar esse canto em curva. Percebo a escola como uma extensão de um bairro, uma comunidade; com isso, minha necessidade de andarilhar. As ruas começaram a se delinear há algum tempo. É um bairro antigo, com moradores quase seculares, cujas primeiras casas estão estabelecidas longe umas das outras.

Uma ou outra praça de convivência é visível, com árvores de copas altas e nenhum lugar para sentar-se. As ruas foram passando de areia avermelhada para lajotas e, depois, para um piche escuro chamado asfalto. (Eu o chamo de fim dos banhos de areia para pardal.)

As casas começaram a brotar, como pequenos cogumelos escondidos debaixo de uma telha depois de uma semana de chuva no verão, e, em segundos, não há mais terrenos vazios. Tudo foi organizado para não ser mais necessário sair do confortável ambiente criado: há tudo na vizinhança. Ledo equívoco vendido pelo conforto.

Nesse lugar, há escolas com professores para todas as propostas de pensamento; desejos comestíveis, feitos a partir de receitas industrializadas, vendidos em cada padaria de esquina; um mercado com uma infinidade de objetos- 


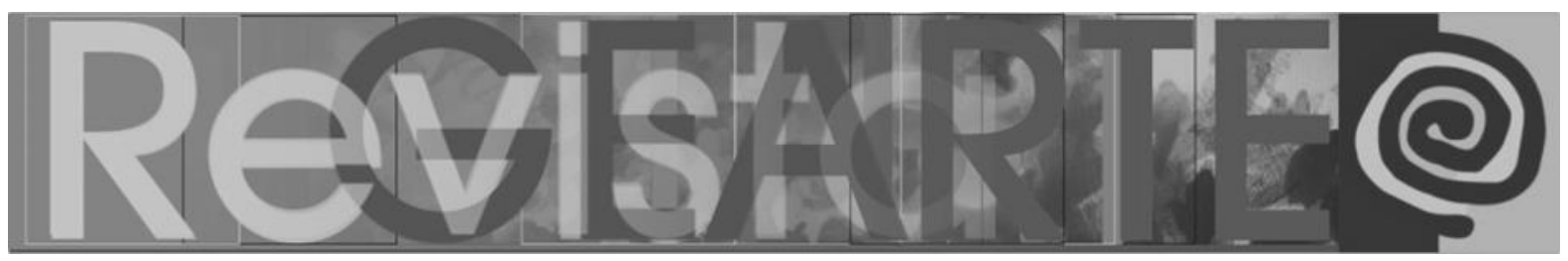

livros-alimentícios embalados em práticas sacolas de plástico; fármacos disponibilizados diretamente nos filtros São João de cada residência; e calçadas tão brancas que seus reflexos quase cegam o transeunte que ousar andarilhar demais.

Percebam, no entanto, que não descrevo os habitantes do bairro. Eles podem ser eu ou você! Eles não são meus personagens, eles o habitam.

Nesse bairro, ou se habita nele de modo condescendente com suas condições, ou se é um eremita desordeiro que nega ficar no mesmo lugar sem ousar sair dele. O estar, nesse caso, é sempre a possibilidade de escapar. Ser um morador desse bairro é torná-lo enfadonho e monótono. É olhar pela janela da sua casa, já sabendo exatamente TUDO que Ihe acontecerá ao atravessar o portão. É deixar criar raízes sobre pisos cerâmicos, que não possuem nutriente algum, a não ser a cerâmica inerte de onde vertem os goles de água entre uma aula e outra.

Estar é tornar-se um estrangeiro em sua própria casa. E como ser um bom vizinho sem ser estrangeiro de si mesmo? Pauso para trazer a figura de linguagem oposta ao que se pode ter lido: aqui o bom está muito longe do sorridente ser que cumprimenta a todos com frases prontas. $\mathrm{O}$ bom é aquele que movimenta em intensidades algumas estruturas pesadas demais para serem aniquiladas, treme um pouco o piso quando anda, ou atravessa o bairro de um ponto a outro sem ser percebido, até cruzar as fronteiras invisíveis demarcadas.

Para Deleuze, a filosofia permite esse meu desejo de estar em vizinhança, num sentido mesmo pré-filosófico, que pode, talvez, partilhar melhor as margens com a arte, a literatura e a educação. "O conceito não tem outra regra senão da vizinhança" (DELEUZE, 2010, p. 109).

Os personagens conceituais convidados para esta escrita estão para a filosofia assim como as figuras estéticas estão para a arte ou a literatura. "A diferença entre os personagens conceituais e as figuras estéticas consiste de início o seguinte: uns são potências de conceitos, os outros, potências de afectos e de 


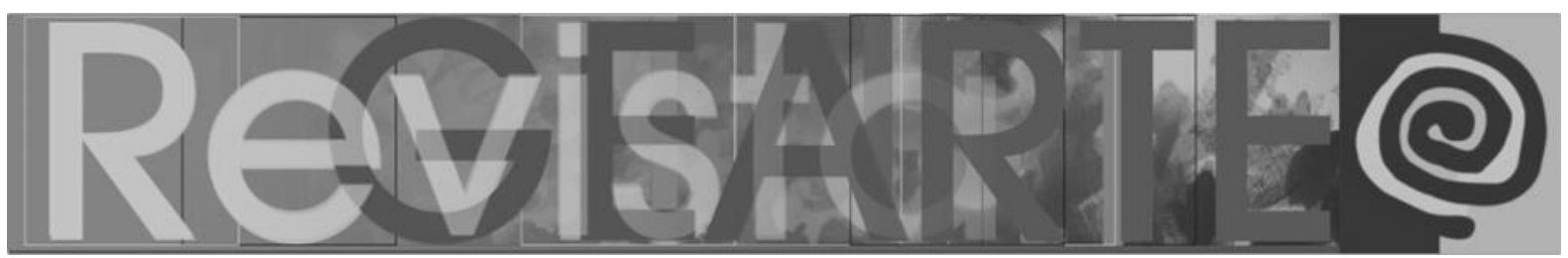

perceptos" (DELEUZE, 2010, p. 80). Com a filosofia e a arte a fabulação flui, extrapolando membranas frágeis da realidade de ser e estar - em formação - na docência em Artes Visuais.

No bairro, conhecer todos parece fazer parte de uma iniciação. Entra-se na casa de todos, sejam eles convidativos ou não; toma-se um café ouvindo histórias de tempos remotos, em que a história tem uma própria curva temporal. Quando pequenos, costuma-se andar de mãos dadas com aqueles mais experientes, que Ihes indicavam o caminho mais rápido para onde gostariam de chegar. Indicavam, também, como escapar das ruas que ainda não eram pavimentadas, onde se esconder em caso de perseguição ou medo iminentes, qual atalho era mais indicado para determinada situação, e até mesmo mostravam quais moradores eram mais ranzinzas e não gostavam de compartilhar um espaço na sombra de uma árvore.

De repente, escorreguei em uma rua que, no lugar de lajotas, possuía uma trilha de areia solta. O susto não foi pelo escorregar nem pelo ralar de joelhos, mas pelo escândalo gerado por estar andando tão desatenta em um lugar como aquele. "Poderia ter acontecido algo pior!" Diziam os poucos que passavam. A desatenção equívoca não era pela escolha do lugar nem pelo caminho. Era pelo descaso destinado àquele lugar.

Assim também é a área da formação docente, pois ela possui estruturas estabelecidas em currículos nacionais cujas aprovações passam por uma série de conselhos e consensos. Para as Artes Visuais não é diferente. A organização curricular prevê um começo e um fim, mas a problemática está na forma congelada em que são dados estes percursos que, no entanto, querem exalar fluidez. Enfatizo: não critico a estrutura de uma universidade nem de uma licenciatura em Artes Visuais, mas questiono como certas imagens na formação são cristalizadas como idealizações passadas por gerações. Essas tornam o caminho claro demais, sem possibilitar vislumbrar os enigmas fantásticos que podem estar à espreita ao olhar um livro proibido no setor obscuro da biblioteca. A fabulação apresenta-se, 


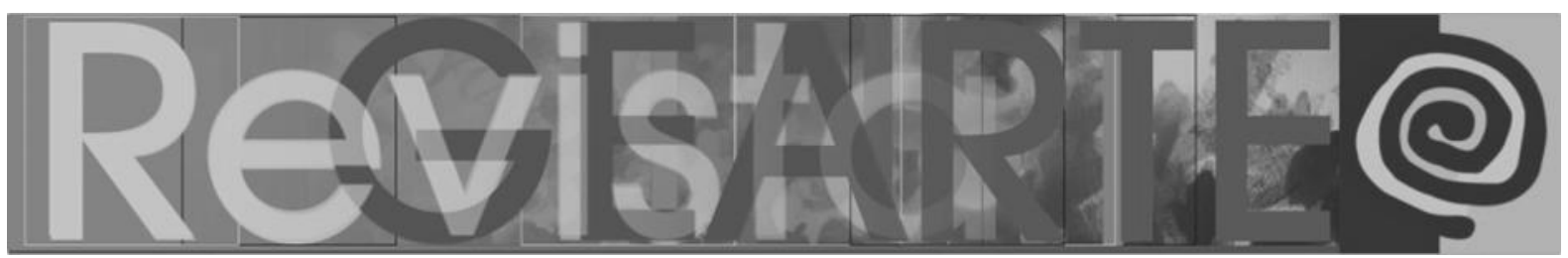

então, como mistério, como ficção para tornar a realidade possível de novo em sua impossibilidade.

Essa realidade impossível de ser colocada nesta conversa partilha do mesmo tempo que narra Qfwfq, ou seja, não é um atravessamento vertical que rompe uma existência e se instala como única: alguém que entra numa faculdade de Artes Visuais pode sair dali formatado e finalizado. Na perspectiva do avizinhamento, a formação ocorre por incontáveis contaminações e acontecimentos, sendo que nosso "bairro Professoralidade" 5 vai deixando de ser para estar.

Quando Bartleby (MELVILLE, 1986) diz: preferiria não, ele nos convida a partilhar de um modo impossível de existir em uma realidade já enquadrada e esquadrinhada. A forma incerta da resposta dada por ele vai à outra fronteira, libertando-se das cristalizações e ousando romper com as linhas pré-programadas de uma existência para não mais ser apenas marionete.

Professores podem vir a ser marionetes quando não fogem do seu destino, fixando suas âncoras com firmeza e baseando-se em fundamentos profundos, aos cuidados de mãos controladoras experientes (não envergonhariam seus mestres que assim teriam discípulos obedientes e condescendentes). A este, talvez, falte 0 qualquer um, ou mesmo um rosto ou um corpo, submersos nessa estranha situação, em que cada um não pode ser qualquer um. Não se trata apenas de questões institucionais ou formativas, mas da possibilidade infinita de criar uma rachadura nas representações do que seria um ser e estar professor. "Entre uma cena e outra houve - há - uma rachadura, não uma fronteira, não um limite, não apenas uma separação. A reconciliação não é fácil. A rachadura é infinita" (SKLIAR, 2014, p. 213).

Para essa rachadura, trago as paisagens conceituais da vizinhança para serem pensadas como figuras e conceitos. Para Deleuze "[...] as figuras são projeções sobre o plano, que implicam algo de vertical ou de transcendente; os 


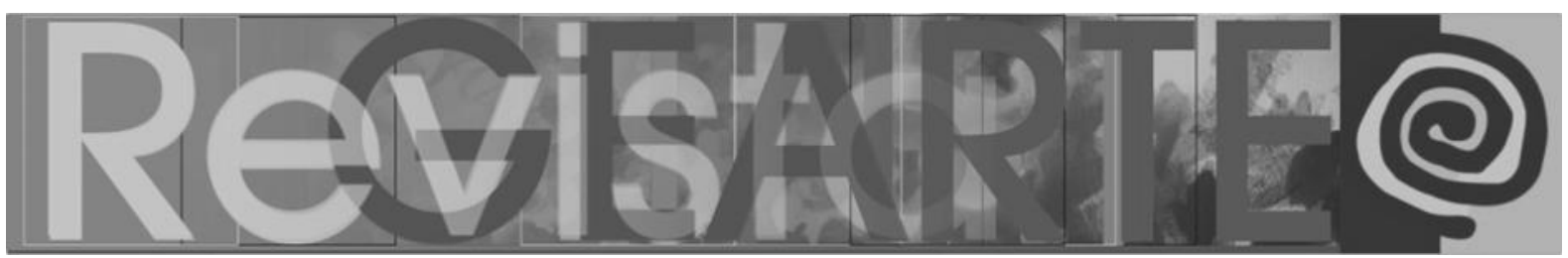

conceitos, em contrapartida, só implicam vizinhanças e conjugações sobre o horizonte" (DELEUZE, 2010, p. 111). Nessa perspectiva, as figuras criam atravessamentos que precisam caminhar em pares com os conceitos, para não serem consumidas por olhares de Medusa.

Para não se transformar em pedra, a formação docente precisa deixar o ressentimento que percorre as salas de aula, os gabinetes e os corredores das universidades, em que se escuta com clareza certo esgotamento do sistema, pois deixaram de ser lugares de estudo para se tornarem "destacadas casas de estudo", apenas para conservar a sua pretensão de destaque (de hierarquia, de entronizar pessoas, grupos e autorias, de separação com a polis). Com isso, perderam seu caráter de casas (lares, atmosferas, microclimas de acolhida e hospitalidade), que põe em jogo o exercício solitário e silencioso do gesto de perceber, pensar, ler e escrever de modo comunitário, de maneira a contribuir com que os docentes em formação habitem o mundo para fazer algo diferente do que fizeram seus antecessores (SKLIAR, 2019, p. 32-33).

Para tanto, pegar uma carona pode evitar infortúnios e também mostrar outras perspectivas de viver em uma comunidade em formação. Como foi dito antes, o bairro em que estamos é curto, mas pode prolongar-se em diagonais criadas por caminhos sobre a grama amassada. Às vezes, estava absorta em perseguir modos de caminhar, receitas de melhoramentos que acabavam findando em algum ingrediente excêntrico ou uma prática alienígena, que não levavam a lugar algum. Nem me dei conta de que quase perdera a carona para a condução. Corri. Corri tanto que me esqueci de que estava ainda na região arenosa. Escorreguei. Levantei-me rapidamente, sacudi a poeira e entrei. E começo a ler um

[...] guia de viagem enquanto o senhor de óculos sorri para a senhora de óculos conferindo o relógio e está bem e vamos e falta muito e não ainda e espere um pouco e sim agora viajantes transitam entre vidas e indas entre passo e despasso entre nem e trem eles param eles pousam num pasmo seja num poço marrom de ceneja corujas caducas murchas (DE CAMPOS, 2004, s/p.). 


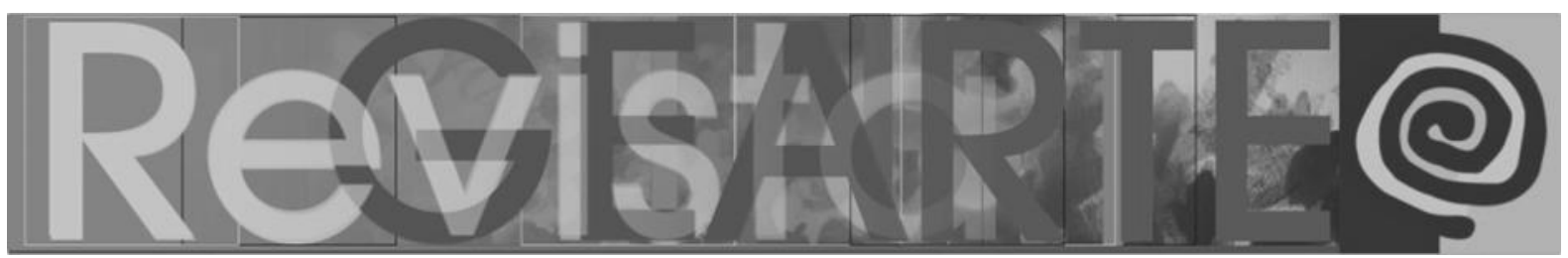

A coruja marrom que idealizei e criei repulsa encarava-me com olhos amarelo-ouro. Seus olhos não eram inquisidores, mas convidativos. Não, não poderia criar penas agora. Não agora, sabendo que poderia escorregar pelas frestas de lugares que não existiam. Não teve como fugir, pois, ao saltar da condução, vi a mim mesma refletida no vidro da porta. Estava emplumada, como outras em formação. Uma pluma fininha e com pouca cor: eram tufos de professor. Irritada com aquilo, tentei arrancar uma por uma, maquiar, esconder, apertar em outras roupas. Demorei a perceber que elas não se proliferaram; continuavam a aparecer sempre nos mesmos lugares. E, quando me dei conta, compreendi que estava tudo bem parecer um pouco coruja caduca. Mas tudo bem também não.

Como ser um romancista, como fabular a vida e a formação? Haruki Murakami faz uma pausa sobre a sua concepção de construção de um romancista para relatar como a escola não fez parte da sua formação, senão como um contraponto extremo a ser seguido: "como a educação escolar foi útil - ou inútil para mim, que sou romancista" (MURAKAMI, 2007, p. 93).

$\mathrm{Na}$ formação docente, aprende-se sobre a escola, no começo longe da escola, perto dos livros, nas "destacadas casas de estudo". Aos poucos, a escola vai ampliando seu papel de protagonista no percurso, até que somos mergulhados por completo em seu cotidiano, com a plumagem da coruja adquirida na formação. A escola como um lugar de regras e formatos não é uma imagem somente para os alunos. Para os professores, é um lugar de ordem, importância e impenetrabilidade - quando não se é aluno, se é professor, não se está ali na escola para aprender, mas para ensinar (eles dizem); não se habitam os mesmos lugares comuns (as salas de professores estão lotadas de professores ocupados com seus cafés quentes), os gritos do pátio são abafados pelos suspiros nas correções de provas intermináveis, assim como os projetores são disputados como recurso de imagem. Murakami fala da antítese entre os saudosos à escola enquanto ele desejaria ter sido mais libertino. Acredito que com os professores é o mesmo: há aqueles que são e os que estão. 


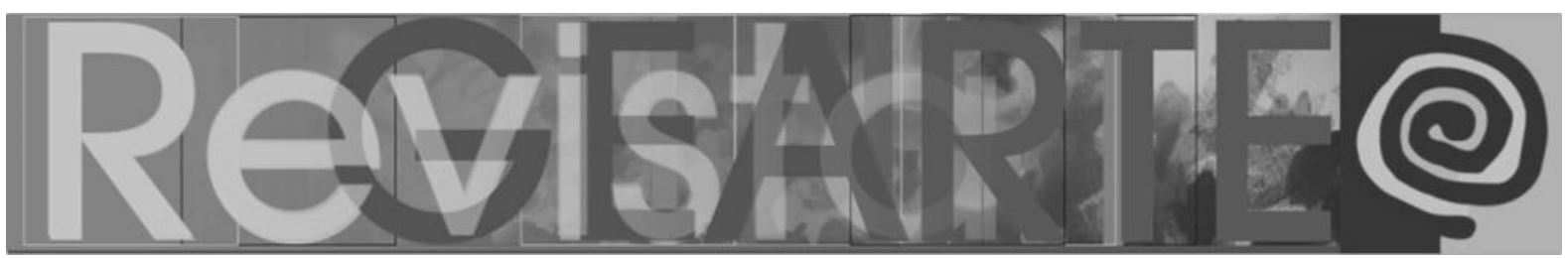

Deleuze foi professor. Ministrou aulas lotadas sobre filosofia em alguns cursos. Ele concorda que a aula "[...] é como um laboratório de pesquisas: dá-se um curso sobre aquilo que se busca e não sobre o que se sabe" (DELEUZE, 2000, p. 173). Não se é um professor de verdades, de afirmativas prontas e já escritas em PowerPoint feitas em computadores antigos. Permita-se estar professor com as aulas, com os alunos, em vizinhança.

Sob a influência de Halfon, relembro o personagem de um professor que atravessa as aulas de literatura e é atravessado pelas literaturas de suas aulas. Em busca do paradeiro de seu aluno Juan, o professor-autor vai até a cidade natal do estudante à sua procura. Ou seria à procura de si próprio? Ao fim do conto, Juan tira a sorte com um canário. "Sorri e sabe que o anoitecer já vem. E o título? Perguntei? Não tem, não acredito em títulos, disse. São um mal necessário, Juan" (HALFON, 2014, p. 7).

Às vezes, os títulos das aulas são males necessários, como cercas que delimitam o começo e o fim da calçada para com o jardim. Outras vezes, podem ser suprimidos e pulverizados como pólen na primavera. Pretendo chegar aos jardins do bairro, para permitir findar este começo-meio de percurso descritivo de estar professor.

Por fim, há praças. São distintas por existirem, pois pressupõem a diferença. Tenho por hábito ficar próximo de uma, não a maior nem a menor, não a mais chamativa nem a mais cativante, mas uma praça que me serve de conforto necessário quando estou em sufocamentos de cinzas. Ali, na brevidade do instante-espaço, tem tudo o que eu preciso para habitar um estar professor na contemporaneidade. Tem a vista, do alto da rua, de vários percursos possíveis. Passam por ali interlocutores necessários, desejantes também por momentos de paz e, por fim, e não menos importante: o caos silencioso atravessado por sons que não se sabe de onde vêm. 


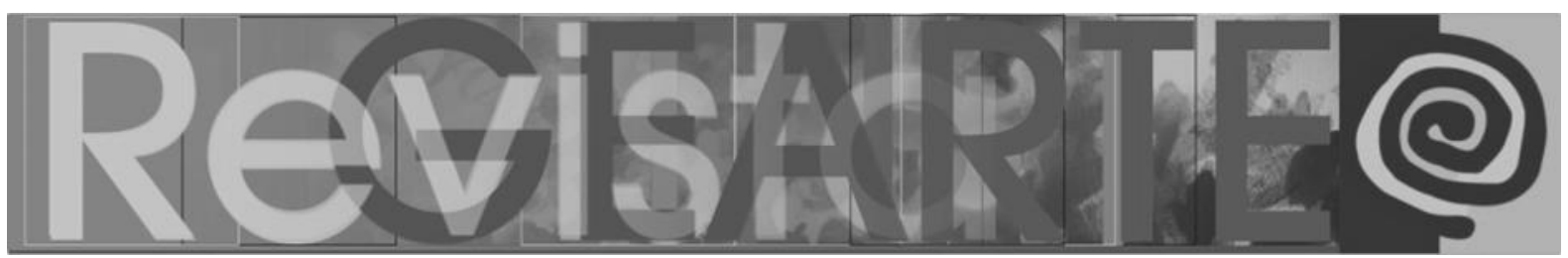

Estar professor é uma multiplicidade, e... e... e... Fico com algumas perguntas soltas no fundo da garganta que ainda precisarão de um tempo a mais para se tornarem densas e escorregarem como pensamento pela língua: se ensina estar professor? Será que a consciência de estar professor não é o perigo de ter se fixado em um lugar confortável? Estar professor, em multiplicidade, pode articular-se com o contemporâneo da/na educação em Artes Visuais? Como posso roubar das artes mais figuras estéticas para manter-me professora?

Morta como Simone de Vila-Matas, volto a adormecer como um sonho contínuo idealizado (um pesadelo?). Domo o tédio e faço uso dele como forças para acordar.

\begin{abstract}
Eram os primeiros minutos do amanhecer. Simone pensou que se não houvesse ninguém interessante nas alturas, teria de procurá-lo em terra firme. Ou não precisava mais procurar nada? Ficou na cama se espreguiçando lentamente, com uma preguiça infinita, observando as partículas de pó que se aglomeravam num raio de sol dentro de seu quarto às escuras. Então ouviu o grito. Alguém havia gritado ao amanhecer, numa casa próxima, talvez em seu próprio imóvel, talvez em seu próprio quarto. Para Simone foi a coisa mais parecida com uma catarse, porque teve a sensação de que em seu despertar ia existir um antes e um depois daquele grito. Logo viu que não seria assim. O grito havia passado e tudo continuava igualmente cinzento e monótono como antes. Voltou a seu tédio e chegou a uma firme conclusão sem que tenha, previamente, se dedicado a procurá-la. A partir daquele momento, enfrentaria diretamente a verdade e suportaria o vazio e, portanto, aceitaria a morte. Afinal de contas, pensou, a verdade se encontra do lado da morte, sempre disse isso. Depois voltou às partículas de pó, aquela espécie de poesia do invisível. Irei além da preguiça do infinito, disse para si. Esta era sua meta na plenitude de seu magnífico despertar de morta. Porque tinha acordado morta, espreguiçando-se suavemente ociosa, esplendorosa (VILA-MATAS, 2013, p. 79).
\end{abstract}

Naquela espécie de poesia do invisível, sinto como se o tempo não passasse. Meu relógio, tecnologia necessária para dar aulas, adaptado agora entre os professores mais virtuais pelo telefone celular, gira seus ponteiros, mas como se não tivesse a mão pesada do tempo lhe dando ordens. Não me encontro, aqui, no tédio, de forma alguma; sinto como se eu fosse precisar de umas duas vidas para explorar todo esse ambiente que me foi possibilitado. Pergunto-me se, ao voltar, estarei a mesma, depois "de ter visto e ouvido coisas demasiadamente grandes" para mim (DELEUZE, 2011, p. 14). Desconfio que nunca estive... 


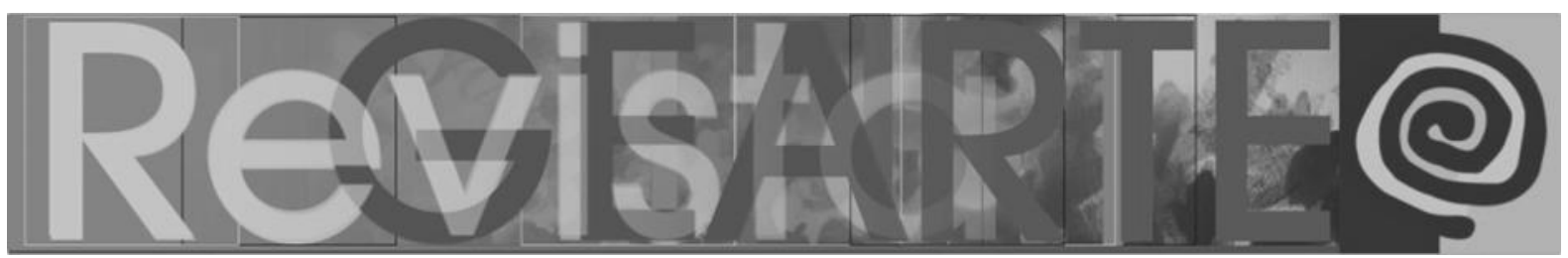

\section{Notas}

1 Essa noção assume, em Deleuze, um significado eminentemente contemporâneo, pois se associa ao in-tempestivo, ao processo de criação de um estilo ou de uma língua estrangeira, tanto na arte quanto na lite-ratura, com uma capacidade tão intensa quanto à vida de recriar continuamente os seus limites. "De modo que compete à função fabuladora inventar um povo" (DELEUZE, 2011, p. 14).

2 Os personagens e incidentes relatados neste artigo são fictícios.

3 O brilho, o esplendor do acontecimento, é o sentido. O acontecimento não é o que acontece (acidente); ele é no que acontece o puro expresso que nos dá sinal e nos espera (DELEUZE, 2003, p. 152).

4 Fictícios ou reais, animados ou inanimados, é preciso fabricar seus próprios intercessores. É uma série. Se não formamos uma série, mesmo que completamente imaginária, estamos perdidos. Eu preciso de meus intercessores para me exprimir, e eles jamais se exprimiriam sem mim: sempre se trabalha em vários, mesmo quando isso não se vê (DELEUZE, 2000, p. 156).

5 "A professoralidade não é uma identidade que o sujeito constrói ou assume ou incorpora, mas de outro modo, é uma diferença que o sujeito produz em si" (PEREIRA, 2013, p. 35).

\section{Referências}

BERGSON, Henri. As duas fontes da moral e da religião. Rio de Janeiro: Zahar, 1978.

CALVINO, Italo. Todas as cosmicômicas. 2. ed. rev. e atual. São Paulo: Companhia das Letras, 2007.

De CAMPOS, Haroldo. Galáxias. São Paulo: Editora 34, 2004.

DELEUZE, Gilles. Conversações. São Paulo: Editora 34, 2000.

DELEUZE, Gilles. Crítica e clínica. 2. ed. São Paulo: Editora 34, 2011.

DELEUZE, Gilles. Diferença e repetição. 2. ed. rev. Rio de Janeiro: Graal, 2006.

DELEUZE, Gilles. Lógica do sentido. São Paulo: Editora Perspectiva, 2003.

DELEUZE, Gilles; GUATTARI, Félix. O que é a filosofia? 2. ed. Rio de Janeiro: Editora 34, 1997.

HALFON, Eduardo. O Boxeador polaco. Rio de Janeiro: Rocco, 2014.

MELVILLE, Herman. Bartleby, o escriturário: uma história de Wall Street. Rio de Janeiro: Rocco, 1986.

MURAKAMI, Haruki. Romancista como vocação. São Paulo: Alfaguara, 2017.

PEREIRA, Marcos Villela. Estética da professoralidade: um estudo crítico sobre a formação do professor. Santa Maria: Ed. da UFSM, 2013.

ANDRADE, Elenise Cristina Pires; SCARELI, Giovana. Signos irrompem e atraversam: pela estrada afora eu vou bem sozinha com meus sweet dreams... In: SCARELI, Giovana; FERNANDES, Priscila (orgs.). O que te move a pesquisar? Ensaio e experimentações com cinema, educação e cartografia. Porto Alegre: Sulina, 2016.

SKLIAR, Carlos. A escuta das diferenças. Porto Alegre: Mediação, 2019.

SKLIAR, Carlos. Desobedecer a linguagem: educar. Belo Horizonte: Autêntica Editora. 2014.

VILA-MATAS, Enrique. Exploradores do abismo. São Paulo: Cosac Naify, 2013. 


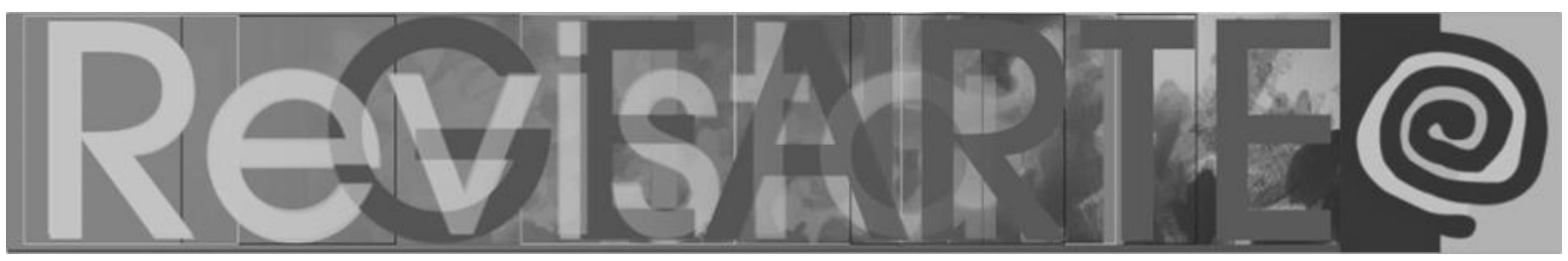

\section{Carolina Ramos Nunes}

Graduação em licenciatura em Artes Visuais pela UDESC (2013). Especialização em Mídias na Educação pela UAB/IFSC (2015). Mestrado em Artes Visuais do PPGAV/UDESC (2017). Doutoranda em Artes Visuais do PPGAV/UDESC (Turma 2018), Linha Ensino das Artes Visuais, sob orientação da Profa Dra Elaine Schmidlin. Arte Educadora da FCBadesc e Prof. Efetiva de Artes na EEB José Matias Zimmermann.

ORCID:https://orcid.org/0000-0002-6847-4603

E-mail: c.nunesra@gmail.com

Currículo:http://lattes.cnpq.br/5448524601348039

\section{Elaine Schmidlin}

Professora no Programa de Pós-Graduação em Artes Visuais e no curso de Licenciatura em Artes Visuais da Universidade do Estado de Santa Catarina (UDESC). Doutora em Educação pela Universidade Federal de Santa Catarina (UFSC) e Membro do Grupo de Pesquisa [Entre] Paisagens UDESC/CNPq, em experimentações com a filosofia da diferença, a arte e a educação.

ORCID: https://orcid.org/0000-0002-7478-1781

E-mail: s.elaine@gmail.com

Currículo:http://lattes.cnpq.br/9781556928615419

Recebido em 6 de julho de 2020 Aceito em 3 de março de 2021 